\title{
Semisyngeneic Hybrid Resistance to Murine Teratocarcinoma Cells
}

\author{
Gail Abendroth Bishop* and William F. Dove
}

McArdle Laboratory for Cancer Research, The University of Wisconsin, Madison, Wisconsin 53706

\begin{abstract}
Resistance to two cultured lines of murine embryonal carcinoma was studied in $\mathrm{F}_{1}$ hybrids constructed between the tumor-syngeneic mouse strain $129 / \mathrm{J}$ and several allogeneic strains. Three of four such hybrid strains were significantly more resistant to the multipotent embryonal carcinoma line PCC3 than the tumor-syngeneic $129 / \mathrm{J}$ parent strain. All hybrid strains tested showed significantly higher resistance to the nullipotent embryonal carcinoma line F9 than the syngeneic strain.

Hybrid resistance to embryonal carcinoma lines does not require a hybrid $H-2$ complex.

Several kinds of evidence indicate that this hybrid resistance has an immunological basis.
\end{abstract}

\section{Introduction}

One of the classic laws of immunogenetics states that $F_{1}$ hybrids produced by crossing two inbred strains will grow tumors indigenous to either parent strain (Snell 1953). This law arises from the fact that histocompatibility alleles are expressed in a codominant manner, so a semisyngeneic $\mathrm{F}_{1}$ hybrid will be tolerant of transplanted tissues originating from either of its two parental strains. However, not long after the formulation of these principles, Hauschka and his colleagues found that $(\mathrm{C} 3 \mathrm{H} / \mathrm{St} \times \mathrm{Swiss}) \mathrm{F}_{1}$ mice were unexpectedly resistant to both a virulent and attenuated line of a lymphosarcoma of $\mathrm{C} 3 \mathrm{H} / \mathrm{St}$ origin (Hauschka et al. 1956). This was followed by Snell's discovery that semisyngeneic $F_{1}$ hybrids show a reduced acceptance of tumor grafts compared to the susceptible parent strain (Snell 1958). These early observations have been repeatedly confirmed in the transplantation of a variety of normal and neoplastic tissues of inbred origin (Cudkowicz 1967, Kiessling

* Present address: Program in Cellular and Molecular Biology, University of Michigan, Ann Arbor, Michigan 48109. 
et al. 1975, Clark et al. 1977, Klein et al. 1978, Sanford and Soo 1971, SchmittVerhulst and Zatz 1977). In all cases, hybrid resistance is a quantitative phenomenon. Unlike the stronger allogeneic resistance, hybrid resistance can be observed only when threshold challenges are used; large doses of cells abolish the effect.

Avner and co-workers (1978) found that $(129 \times \mathrm{C} 57 \mathrm{BL} / 6) \mathrm{F}_{1}$ hybrids showed hybrid resistance to the murine embryonal carcinoma cell line F9. The work we present here examines $F_{1}$ hybrid resistance to the nullipotent line F9 and to the multipotent line PCC3. We examine resistance to the tumor cells in several different semisyngeneic $F_{1}$ hybrid hosts, and we determine whether such resistance is controlled by factors closely linked to the $H-2$ complex. Finally, we investigate whether the resistance of the $(\mathrm{C} 57 \mathrm{BL} / 6 \times 129 / \mathrm{J}) \mathrm{F}_{1}$ hybrid to F9 is immunological in nature.

\section{Materials and Methods}

Mouse strains. The inbred mouse strains 129/J-"129"-, A/J-“A"-, and SJL/J-"S"-, the congenic strain B10.129(6M)-"6M"-, and the $\mathrm{F}_{1}$ hybrid strain $(\mathrm{C} 57 \mathrm{BL} / 6 \times 129 / \mathrm{J}) \mathrm{F}_{1}$ " $(\mathrm{B} 6 \times 129) \mathrm{F}_{1}$ "- were obtained from the Jackson Laboratory, Bar Harbor, Maine. $F_{1}$ hybrid mice between strain 129 and strains A, S, and 6M were bred in our own laboratory. At the start of an experiment, all mice were between 6 and 10 weeks old. The sex of the 129 parent had no detectable effect on the tumor incidence of the $F_{1}$ offspring.

Teratocarcinoma cell lines. The murine embryonal carcinoma cell lines F9-41-"F9"- and PCC3/A/1"PCC3"-, syngeneic in 129/Sv mice, were employed in these experiments. Both these lines were isolated from transplantable teratocarcinoma OTT6050, obtained by L.C. Sievens from the grafting of a $129 / \mathrm{SvS}^{\mathrm{J}} /+$ embryo to the testis of an adult mouse (Stevens 1970). The PCC3 line is developmentally multipotent; the F9 line is nullipotent. Karyotypically, F9 is aneuploid, whereas PCC3 is nearly diploid (Jacob 1977).

Cell culture conditions. Cells were grown in Dulbecco's modified Eagle's medium containing 15\% Gibco fetal calf serum. The cultures were maintained at $37^{\circ} \mathrm{C}$ in a $\mathrm{CO}_{2}$ /humid air mixture. Cultures were harvested and resuspended in fresh medium every $2-3$ days.

Histological analysis of tumors. A sample of tumors from both control and experimental animals was analyzed histologically for each experimental group. Tumors were fixed in Bouin's fixative, paraffinprocessed according to Method I described in Luna (1968), and stained with hematoxylin-eosin. F9 tumors contain only embryonal carcinoma with rare endodermal tissue areas. PCC3 tumors contain derivatives of all three germ layers.

PCC 3 and F9 cell injections. Cells were harvested by pipetting and resuspended in medium containing $1 \%$ fetal calf serum. Cell viability was tested on all samples with the trypan blue dye exclusion test, and all doses are stated as number of viable cells injected. One-milliliter syringes fitted with 22 -gauge needles were used for all injections; all injections were completed within $30 \mathrm{~min}$ of cell harvesting. Cells were injected subcutaneously, bilaterally, in volumes of $0.2 \mathrm{ml}$.

Tumor scoring. Animals were scored for tumors regularly by palpation for a period three times as long as that required for tumor production in the 129 control animals. Animals scored as negative throughout this period were necropsied to confirm the lack of tumors. Results were pooled for male and female recipients, since no sex-related differences in tumor incidence were noted.

Sublethal irradiation of mice. Mice were irradiated with a ${ }^{137} \mathrm{Cs}$ source providing a dose rate of 1000 $\mathrm{rad} /$ minute. The sublethal dose used for $(\mathrm{B} 6 \times 129) \mathrm{F}_{1}$ hybrids was $650 \mathrm{rad}$.

Lymphoid reconstitution of mice. A lethal dose of $900 \mathrm{rad}$ was given to 129 mice from the same ${ }^{137} \mathrm{Cs}$ source. Lymphoid cells were taken from the bone matrow and the spleen of donor $(\mathrm{B} 6 \times 129) \mathrm{F}_{1}$ mice. Each irradiated animal received $10^{7}$ bone marrow and $10^{7}$ spleen cells intravenously through the tail vein. Reconstituted animals were challenged 4 weeks later. 
Immunizations. $(\mathrm{B} 6 \times 129) \mathrm{F}_{1}$ animals received bilateral subcutaneous injections of $1.2 \times 10^{4}$ viable F9 cells and were challenged with a lethal dose $\left(2 \times 10^{5}\right)$ of F9 cells 14 days later. Animals developing tumors prior to the second challenge ( 8 of 72 ) were not included in the results.

Quantitative analysis of results. Dose-response data and comparisons of resistance between hybrid strains were analyzed according to the Wilcoxon signed rank test (Conover 1971);2 2 contingency tests were performed upon results of experiments testing for the effects of preimmunization with live tumor cells, of sublethal irradiation, or of adoptive transfer of lymphoid tissues. In Tables 2,3 , and $4, \triangle=$ the number of tumor-positive 129 mice - the number of tumor-positive $F_{1}$ mice. Absolute $\triangle$ values were assigned ranks, the lowest rank corresponding to the lowest absolute $\triangle$ value. In the case of ties, each member of a tie was assigned a midrank value. $T=$ the sum of all the negative $\triangle$ values. Given the null hypothesis that the tumor incidence of the $F_{1}$ hybrid will not differ significantly from that of the $129 / \mathrm{J}$ parent, the probability of $\mathrm{T}$ was calculated using a Wilcoxon signed-rank distribution. $\mathrm{N}=$ the number of doses tested.

In Tables 5, 6, and 7, data were analyzed by a $2 \times 2$ contingency test according to the following formula:

$$
\begin{aligned}
& \text { Given a matrix a } \quad a \\
& \text { c d } \\
& \text { where } a+b+c+d=N \\
& T=\frac{N(a d-b c)^{2}}{(a+b)(c+d) \times(a+c)(b+d)}
\end{aligned}
$$

The probability of $\mathrm{T}$ was calculated using a Chi-square distribution.

\section{Results}

Previous experiments have shown that $(\mathrm{B} 6 \times 129) \mathrm{F}_{1}$ hybrids are resistant to low doses of F9 (Avner et al. 1978). We have extended this observation to examine resistance to both $\mathrm{F} 9$ and $\mathrm{PCC} 3$ at a number of cell doses in four different $\mathrm{F}_{1}$ hybrid hosts. $F_{1}$ hybrids were constructed between the syngeneic mouse strain 129 and the allogeneic strains $\mathrm{B} 6,6 \mathrm{M}, \mathrm{A}$, and $\mathrm{S}$. These allogeneic strains are all highly resistant to PCC3 (Avner et al. 1978). Strains B6 and 6M are also highly resistant to F9, but A and $\mathrm{S}$ mice are susceptible to moderate $\left(\geq 2 \times 10^{5}\right)$ doses of $F 9$ (Avner et al. 1978). The $H-2$ haplotype of each of these $F_{1}$ hybrid strains is given in Table 1 . Strain $6 \mathrm{M}$ is a congenic strain, possessing the $H-2$ region of 129 on the genetic background of C57BL/10 (Klein 1975). The 129 haplotype $H-2^{\text {bvi }}$ is a minor variant of the $H-2^{\mathrm{b}}$ haplotype, serologically indistinguishable from $H-2^{\text {b }}$ (Klein 1975).

Resistance of $F_{1}$ hybrids to PCC3 and F9. Results of experiments using PCC3 are presented in Table 2. Each hybrid strain was challenged with doses ranging from

Table 1. H-2 haplotypes of $\mathrm{F}_{1}$ hybrid mouse strains

\begin{tabular}{lll}
\hline Mouse strain & & $H-2$ haplotype \\
\hline $\mathrm{C} 57 \mathrm{BL} / 6$ & $\times 129 / \mathrm{J}$ & $\mathrm{b} / \mathrm{bv1}$ \\
$\mathrm{B} 10.129(6 \mathrm{M})$ & $\times 129 / \mathrm{J}$ & $b v 1 / b v 1$ \\
$\mathrm{~A} / \mathrm{J}$ & $\times 129 / \mathrm{J}$ & $a / b v 1$ \\
$\mathrm{SJL} / \mathrm{J}$ & $\times 129 / \mathrm{J}$ & $\mathrm{s} / \mathrm{bv1}$ \\
\hline
\end{tabular}


Table 2. Tumor incidence of $F_{1}$ hybrids challenged with PCC3

\begin{tabular}{|c|c|c|c|c|}
\hline (a) & $\mathrm{B} 6 \times 129$ & & & \\
\hline $\begin{array}{l}\text { Cell } \\
\text { dose }\end{array}$ & $\begin{array}{l}\text { Tumor } \\
\text { incidence- } F_{1}\end{array}$ & $\begin{array}{l}\text { Tumor } \\
\text { incidence- } 129\end{array}$ & $\triangle$ & Rank of $|\triangle|$ \\
\hline $4 \times 10^{5}$ & $10 / 10$ & $10 / 10$ & 0 & 1 \\
\hline $2 \times 10^{5}$ & $8 / 10$ & $10 / 10$ & +2 & 2.5 \\
\hline $1 \times 10^{5}$ & $7 / 10$ & $10 / 10$ & +3 & 4 \\
\hline $5 \times 10^{4}$ & $0 / 20$ & $12 / 20$ & +12 & 6 \\
\hline $2.5 \times 10^{4}$ & $12 / 30$ & $16 / 30$ & +4 & 5 \\
\hline $1.25 \times 10^{4}$ & $5 / 20$ & $3 / 20$ & -2 & 2.5 \\
\hline
\end{tabular}

Sum of ranks of negative $\triangle{ }^{\prime} \mathrm{s}=\mathrm{T}=2.5$. For $\mathrm{N}=6, \mathrm{P}=0.0625$.

\begin{tabular}{|c|c|c|c|c|}
\hline (b) & $6 \mathrm{M} \times 129$ & & & \\
\hline $\begin{array}{l}\text { Cell } \\
\text { dose }\end{array}$ & $\begin{array}{l}\text { Tumor } \\
\text { incidence- } F_{1}\end{array}$ & $\begin{array}{l}\text { Tumor } \\
\text { incidence-129 }\end{array}$ & $\triangle$ & Rank of $|\triangle|$ \\
\hline $1 \times 10^{6}$ & $10 / 10$ & $10 / 10$ & 0 & 1 \\
\hline $3.3 \times 10^{5}$ & $5 / 10$ & $10 / 10$ & +5 & 4.5 \\
\hline $2 \times 10^{5}$ & $4 / 10$ & $8 / 10$ & +4 & 2.5 \\
\hline $1 \times 10^{5}$ & $4 / 10$ & $10 / 10$ & +4 & 2.5 \\
\hline $5 \times 10^{4}$ & $0 / 10$ & $5 / 10$ & +5 & 4.5 \\
\hline
\end{tabular}

Sum of ranks of negative $\triangle{ }^{\prime} \mathrm{s}=\mathrm{T}=0$. For $\mathrm{N}=5, \mathrm{P}=0.031$.

\begin{tabular}{lcccc}
\hline c) & $\mathrm{A} \times 129$ & & \\
\hline $\begin{array}{l}\text { Cell } \\
\text { dose }\end{array}$ & $\begin{array}{l}\text { Tumor } \\
\text { incidence- } F_{1}\end{array}$ & $\begin{array}{l}\text { Tumor } \\
\text { incidence-129 }\end{array}$ & $\Delta$ & Rank of $|\triangle|$ \\
\hline $3.3 \times 10^{5}$ & $10 / 10$ & $10 / 10$ & 0 & 1 \\
$2 \times 10^{5}$ & $9 / 10$ & $10 / 10$ & +1 & 2.5 \\
$1 \times 10^{5}$ & $7 / 10$ & $9 / 10$ & +2 & 4 \\
$5 \times 10^{4}$ & $4 / 10$ & $8 / 10$ & +4 & 5 \\
$3.3 \times 10^{4}$ & $0 / 10$ & $1 / 10$ & +1 & 2.5 \\
\hline
\end{tabular}

Sum of all ranks of negative $\triangle^{\prime} \mathrm{s}=\mathrm{T}=0$. For $\mathrm{N}=5, \mathrm{P}=0.0313$.

\begin{tabular}{|c|c|c|c|c|}
\hline (d) & $\mathrm{S} \times 129$ & & & \\
\hline $\begin{array}{l}\text { Cell } \\
\text { dose }\end{array}$ & $\begin{array}{l}\text { Tumor } \\
\text { incidence-F }\end{array}$ & $\begin{array}{l}\text { Tumor } \\
\text { incidence-129 }\end{array}$ & $\triangle$ & Rank of $|\triangle|$ \\
\hline $3.3 \times 10^{5}$ & $19 / 19$ & $19 / 19$ & 0 & 1 \\
\hline $2 \times 10^{5}$ & $10 / 10$ & $9 / 10$ & -1 & 2.5 \\
\hline $1 \times 10^{5}$ & $6 / 10$ & $9 / 10$ & +3 & 5 \\
\hline $5 \times 10^{4}$ & $7 / 10$ & $9 / 10$ & +2 & 4 \\
\hline $3.3 \times 10^{4}$ & $0 / 10$ & $1 / 10$ & +1 & 2.5 \\
\hline
\end{tabular}

Sum of ranks of negative $\triangle^{\prime} \mathrm{s}=\mathrm{T}=2.5$. For $\mathrm{N}=5, \mathrm{P}=0.125$. 
one that yielded $100 \%$ tumors to another that yielded virtually $0 \%$ tumors in the hybrid hosts. All hybrids tested, with the exception of the $(\mathrm{S} \times 129) \mathrm{F}_{1}$, showed significantly higher resistance to PCC3 than the tumor-syngeneic 129 parent.

Results of experiments using F9 are presented in Table 3. Hybrid strains were tested again over a dose range yielding from $100 \%$ to $0 \%$ tumors. All four of the hybrid strains showed significant $F_{1}$ resistance to $F 9$.

Table 3. Tumor incidence of $F_{1}$ hybrids challenged with F9

\begin{tabular}{|c|c|c|c|c|c|}
\hline \multirow{2}{*}{\multicolumn{2}{|c|}{$\begin{array}{l}\text { (a) } \\
\text { Cell } \\
\text { dose }\end{array}$}} & \multicolumn{4}{|l|}{$B 6 \times 129$} \\
\hline & & $\begin{array}{l}\text { Tumor } \\
\text { incidence- } F_{1}\end{array}$ & $\begin{array}{l}\text { Tumor } \\
\text { incidence-1 } 29\end{array}$ & $\triangle$ & Rank of $|\triangle|$ \\
\hline 2 & $\times 10^{5}$ & $10 / 10$ & $10 / 10$ & 0 & 1.5 \\
\hline 1 & $\times 10^{5}$ & $9 / 10$ & $10 / 10$ & +1 & 3 \\
\hline 5 & $\times 10^{4}$ & $2 / 10$ & $10 / 10$ & +8 & 8.5 \\
\hline 2.5 & $\times 10^{4}$ & $0 / 10$ & $10 / 10$ & +10 & 10 \\
\hline 1.25 & $5 \times 10^{4}$ & $2 / 10$ & $10 / 10$ & +8 & 8.5 \\
\hline 6 & $\times 10^{3}$ & $0 / 10$ & $6 / 10$ & +6 & 6 \\
\hline 3 & $\times 10^{3}$ & $2 / 10$ & $9 / 10$ & +7 & 7 \\
\hline 1.5 & $\times 10^{3}$ & $0 / 10$ & $2 / 10$ & +2 & 4 \\
\hline 7.5 & $\times 10^{2}$ & $0 / 10$ & $3 / 10$ & +3 & 5 \\
\hline 3.75 & $5 \times 10^{2}$ & $0 / 10$ & $0 / 10$ & 0 & 1.5 \\
\hline
\end{tabular}

Sum of ranks of negative $\triangle \mathrm{s}=\mathrm{T}=0$. For $\mathrm{N}=10, \mathrm{P}=0.001$.

\begin{tabular}{|c|c|c|c|c|}
\hline \multirow{2}{*}{$\begin{array}{l}\text { (b) } \\
\text { Cell } \\
\text { dose }\end{array}$} & \multicolumn{4}{|l|}{$6 \mathrm{M} \times 129$} \\
\hline & $\begin{array}{l}\text { Tumor } \\
\text { incidence- } F_{1}\end{array}$ & $\begin{array}{l}\text { Tumor } \\
\text { incidence- } 129\end{array}$ & $\triangle$ & Rank of $|\triangle|$ \\
\hline $5 \times 10^{5}$ & $10 / 10$ & $10 / 10$ & 0 & 1 \\
\hline $2 \times 10^{5}$ & $7 / 10$ & $10 / 10$ & +3 & 2 \\
\hline $1 \times 10^{5}$ & $4 / 10$ & $10 / 10$ & +6 & 3 \\
\hline $5 \times 10^{4}$ & $2 / 10$ & $10 / 10$ & +8 & 5 \\
\hline $2.5 \times 10^{4}$ & $2 / 17$ & $13 / 17$ & +11 & 6 \\
\hline $1.25 \times 10^{4}$ & $0 / 10$ & $7 / 10$ & +7 & 4 \\
\hline
\end{tabular}

Sum of ranks of negative $\triangle$ 's $=\mathrm{T}=0$. For $\mathrm{N}=6, \mathrm{P}=0.0156$.

\begin{tabular}{lcccc}
\hline (c) & $\mathrm{A} \times 129$ & & \\
\hline $\begin{array}{l}\text { Cell } \\
\text { dose }\end{array}$ & $\begin{array}{c}\text { Tumor } \\
\text { incidence- } F_{1}\end{array}$ & $\begin{array}{c}\text { Tumor } \\
\text { incidence-129 }\end{array}$ & & Rank of $|\triangle|$ \\
\hline $2 \times 10^{5}$ & $10 / 10$ & $10 / 10$ & 0 & 1 \\
$1 \times 10^{5}$ & $7 / 10$ & $10 / 10$ & +3 & 4 \\
$5 \times 10^{4}$ & $16 / 20$ & $17 / 20$ & +1 & 2 \\
$2.5 \times 10^{4}$ & $5 / 10$ & $8 / 10$ & +3 & 4 \\
$1.25 \times 10^{4}$ & $12 / 20$ & $16 / 20$ & +4 & 6 \\
6 & $0 / 10$ & $3 / 10$ & +3 & 4 \\
\hline
\end{tabular}

Sum of ranks of negative $\triangle^{\prime} \mathrm{s}=\mathrm{T}=0$. For $\mathrm{N}=6, \mathrm{P}=0.0156$. 
Table 3. Continued.

\begin{tabular}{lllll}
\hline d) & $\mathrm{S} \times 129$ & & \\
Cell & $\begin{array}{l}\text { Tumor } \\
\text { incidence- } \mathrm{F}_{1}\end{array}$ & $\begin{array}{l}\text { Tumor } \\
\text { incidence- } 129\end{array}$ & & Rank of $\mid \triangle \mathrm{l}$ \\
\hline $2 \times 10^{5}$ & $10 / 10$ & $10 / 10$ & 0 & 1.5 \\
$1 \times 10^{5}$ & $9 / 10$ & $10 / 10$ & +1 & 4 \\
$5 \times 10^{4}$ & $7 / 10$ & $10 / 10$ & +3 & 7 \\
$2.5 \times 10^{4}$ & $6 / 10$ & $7 / 10$ & +1 & 4 \\
$1.25 \times 10^{4}$ & $6 / 10$ & $10 / 10$ & +4 & 8 \\
$6 \times 10^{3}$ & $8 / 10$ & $9 / 10$ & +1 & 4 \\
$3 \times 10^{3}$ & $3 / 10$ & $5 / 10$ & +2 & 6 \\
$1.5 \times 10^{3}$ & $4 / 10$ & $4 / 10$ & 0 & 1.5 \\
\hline
\end{tabular}

Sum of ranks of negative $\triangle \mathrm{s}=\mathrm{T}=0$. For $\mathrm{N}=8, \mathrm{P}=0.0039$.

When the magnitude of hybrid resistance to $\mathrm{F} 9$ was examined, it was discovered that the strains fall into two groups. Strains $(\mathrm{B} 6 \times 129) \mathrm{F}_{1}$ and $(6 \mathrm{M} \times 129) \mathrm{F}_{1}$ belong to a high resistance category, whereas strains $(\mathrm{A} \times 129) \mathrm{F}_{1}$ and $(\mathrm{S} \times 129) \mathrm{F}_{1}$ belong to

Table 4. Comparison of strength of hybrid resistance to F9 between $F_{1}$ strains

\begin{tabular}{|c|c|c|c|c|}
\hline \multirow{3}{*}{$\begin{array}{l}\text { (a) } \\
\text { Cell } \\
\text { dose }\end{array}$} & \multicolumn{4}{|c|}{$(\mathrm{B} 6 \times 129) \mathrm{F}_{1}$ vs. $(6 \mathrm{M} \times 129) \mathrm{F}_{1}$} \\
\hline & \multirow{2}{*}{\multicolumn{2}{|c|}{$\begin{array}{l}\% \text { Tumor-negative } \\
F_{1} \text { mice }\end{array}$}} & \multirow[t]{3}{*}{$\triangle$} & \multirow[t]{3}{*}{ Rank of $|\triangle|$} \\
\hline & & & & \\
\hline & $(\mathrm{B} 6 \times 129) \mathrm{F}_{1}$ & $(6 \mathrm{M} \times 129) \mathrm{F}_{1}$ & & \\
\hline $2 \times 10^{5}$ & 0 & 0 & 0 & 1.5 \\
\hline $1 \times 10^{5}$ & 10 & 60 & -50 & 5 \\
\hline $5 \times 10^{4}$ & 80 & 80 & 0 & 1.5 \\
\hline $2.5 \times 10^{4}$ & 100 & 64 & +36 & 4 \\
\hline $1.25 \times 10^{4}$ & 80 & 70 & +10 & 3 \\
\hline
\end{tabular}

Sum of ranks of negative $\triangle \mathrm{s}=\mathrm{T}=5$.

For $\mathrm{N}=5, \mathrm{P}=0.3125$.

\begin{tabular}{|c|c|c|c|c|}
\hline \multirow{2}{*}{ 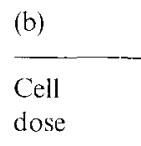 } & \multicolumn{4}{|c|}{$(\mathrm{A} \times 129) \mathrm{F}_{1}$ vs. $(\mathrm{S} \times 129) \mathrm{F}_{1}$} \\
\hline & $\begin{array}{l}\% \text { Tumor-negative } \\
\mathrm{F}_{1} \text { mice }\end{array}$ & $\begin{array}{l}\% \text { Tumor-negative } \\
129 \text { controls }\end{array}$ & $\triangle$ & Rank of $|\triangle|$ \\
\hline & $(\mathrm{A} \times 129) \mathrm{F}_{1}$ & $(\mathrm{~S} \times 129) \mathrm{F}_{1}$ & & \\
\hline $2 \times 10^{5}$ & 0 & 0 & 0 & 1 \\
\hline $1 \times 10^{5}$ & 30 & 10 & +20 & 3 \\
\hline $5 \times 10^{4}$ & 5 & 30 & -25 & 5 \\
\hline $2.5 \times 10^{4}$ & 30 & 10 & +20 & 3 \\
\hline $1.25 \times 10^{4}$ & 20 & 40 & -20 & 3 \\
\hline
\end{tabular}

Sum of ranks of negative $\triangle{ }^{\prime} \mathrm{s}=\mathrm{T}=8$.

For $\mathrm{N}=5, \mathrm{P}=0.59$. 
Table 4. Continued.

\begin{tabular}{|c|c|c|c|c|}
\hline \multirow{3}{*}{$\begin{array}{l}\text { (c) } \\
\text { Cell } \\
\text { dose }\end{array}$} & \multicolumn{4}{|l|}{ "C57" $F_{1}$ vs. "A, S" $F_{1}$} \\
\hline & \multirow{2}{*}{$\begin{array}{l}\% \text { Tumor-negative } \\
\mathrm{F}_{1} \text { mice }\end{array}$} & \multirow{2}{*}{$\begin{array}{l}\% \text { Tumor-negative } \\
129 \text { controls }\end{array}$} & \multirow[t]{3}{*}{$\triangle$} & \multirow[t]{3}{*}{ Rank of $|\triangle|$} \\
\hline & & & & \\
\hline & "C57" $\mathrm{F}_{1}$ & "A, S" $F_{1}$ & & \\
\hline $2 \times 10^{5}$ & 0 & 0 & 0 & 1 \\
\hline $1 \times 10^{5}$ & 35 & 20 & +15 & 2 \\
\hline $5 \times 10^{4}$ & 80 & 13 & +65 & 5 \\
\hline $2.5 \times 10^{4}$ & 78 & 20 & +58 & 4 \\
\hline $1.2 \times 10^{4}$ & 75 & 27 & +48 & 3 \\
\hline
\end{tabular}

Sum of ranks of negative $\Delta^{\prime} s=T=0$. For $N=5, p=0.031$.

a low resistance group (Table 4, parts a and b). Data from each group were pooled and compared (Table 4, part c). It was found that hybrid resistance to F9 was significantly stronger in the "C57" group than in the "A, $\mathrm{S}$ " group $(\mathrm{P}=0.03)$. This may indicate the presence of a strong factor for hybrid resistance in the C57BL background (common to the $\mathrm{B} 6$ and $6 \mathrm{M}$ strains) that is absent in the $\mathrm{A}$ and $\mathrm{S}$ strain backgrounds.

Evidence that hybrid resistance to $F 9$ is an immunological response. The $(\mathrm{B} 6 \times 129) \mathrm{F}_{1}$ hybrid strain, which demonstrated strong $F_{1}$ resistance to $F 9$ and significant resistance to $\mathrm{PCC} 3$, was chosen for further studies. The first of these involved an attempt to increase the hybrid resistance by preimmunizing with sublethal doses of viable F9 cells. The immunization procedure is described in Materials and Methods. The results, presented in Table 5 , show that preimmunized $F_{1}$ were significantly more resistant to challenge with lethal doses of $\mathrm{F} 9$ than their nonimmunized counterparts $\left(\mathrm{X}^{2}=4.5 ; \mathrm{P}=0.02\right)$. A more conservative estimate of the level of significance would classify the eight animals that incurred tumors from the preimmunization dose as tumor-positive in the set of challenged animals. This estimate gives $\mathrm{X}^{2}=2.56, \mathrm{P}=0.04$.

Total-body irradiation with sublethal levels of X-rays eliminates many immunological responses. Avner and co-workers (1978) found that sublethal total-body irradiation diminished the resistance to $\mathrm{F} 9$ of $(\mathrm{B} 6 \times 129) \mathrm{F}_{1}$ hybrids. Our results (Table 6) confirm this observation. Sublethally irradiated $(\mathrm{B} 6 \times 129) \overrightarrow{\mathrm{F}}_{1}$ mice were unable to resist a sublethal dose of $\mathrm{F} 9$ cells to which unirradiated control hybrids showed a high degree of resistance $\left(\mathrm{X}^{2}=25.1 ; \mathrm{P}<0.001\right)$.

Adoptive transfer of immunocompetent cells provides a positive test for the immunological basis of a response. Thus, the capacity of the $(\mathrm{B} 6 \times 129) \mathrm{F}_{1}$ hybrid to transfer its resistance to the tumor-permissive 129 parent strain was tested. Construction of $129 \longleftarrow \mathrm{F}_{1}$ radiation chimeras is described in Materials and Methods; results are presented in Table 7 . The chimeras showed a highly significant increase in resistance to $\mathrm{F} 9$ ( $\left.\mathrm{part} \mathrm{a} ; \mathrm{X}^{2}=11.75 ; \mathrm{p}<0.001\right)$; this resistance approached that of the $\mathrm{F}_{1}$ hybrid itself (part $\mathrm{b} ; \mathrm{X}^{2}=1.2 ; \mathrm{p}>0.16$ ). 
Table 5. Immunization of $(\mathrm{B} 6 \times 129) \mathrm{F}_{1}$ mice

\begin{tabular}{llll}
\hline & Total & Tumor-negative & Tumor-positive \\
\hline Control hybrids & 72 & $19(26 \%)$ & $53(74 \%)$ \\
Immunized hybrids & 64 & $28(44 \%)$ & $36(56 \%)$ \\
\hline
\end{tabular}

Hybrids were immunized with sublethal doses of F9, as described in Materials and Methods. These animals and their age- and sex-matched controls were challenged at the same time with $2 \times 10^{5} \mathrm{~F} 9 \mathrm{cells}$ from the same preparation.

\section{Discussion}

The present experiments extend previous observations on $F_{1}$ hybrid resistance to murine embryonal carcinoma cells (Avner et al. 1978). We have studied resistance to both multipotent and nullipotent cell lines of a murine teratocarcinoma in four strains of $F_{1}$ mice semisyngeneic to the strain of tumor origin.

Most of the $F_{1}$ hybrid strains showed significant resistance to both embryonal carcinoma cell lines PCC3 and F9. Our results concerning the $H-2$ control of this hybrid resistance fit the pattern described by Klein and co-workers (1978), who reported that $\mathrm{F}_{1}$ hybrid resistance to three carcinomas and two sarcomas failed to show significant linkage to the $H-2$ complex. In the present studies, the hybrid $(6 \mathrm{M} \times 129) \mathrm{F}_{1}$ showed undiminished resistance to both embryonal carcinoma cell lines tested, although the $H-2$ haplotype of this hybrid is homozygous and identical to that of the inbred syngeneic 129 parent. Resistance of the $(6 \mathrm{M} \times 129) \mathrm{F}_{1}$ hybrid was equal in strength to that of the $H-2$ heterozygote $(\mathrm{B} 6 \times 129) \mathrm{F}_{1}$. Thus, we conclude that heterozygosity of the $H-2$ region is not necessary to account for hybrid resistance to the embryonal carcinoma cell lines PCC3 and F9.

Avner and co-workers (1978) showed that B6 carries strong allograft rejection character(s) for $\mathrm{F} 9$, whereas $\mathrm{A}$ and $\mathrm{S}$ do not. It is possible that the same character(s) responsible for this difference in allograft rejection continues to operate in the semisyngeneic hybrid host. This could account for the greater hybrid resistance of the "C57BL" group (Table 4). In principle, such a character could be either a dominant immune-response factor in the B6 genome or else a strong histocompatibility difference for which the 129 allele is incompletely expressed in the $F_{1}$ hybrid.

The basis of resistance in the $(\mathrm{B} 6 \times 129) \mathrm{F}_{1}$ mouse to $\mathrm{F} 9$ appears to be an immune response to an antigenic determinant (or determinants) present on the embryonal carcinoma cell. This conclusion stems from the observations that: (a) $F_{1}$ hybrid

Table 6. Sensitivity of sublethally irradiated $(\mathrm{B} 6 \times 129) \mathrm{F}_{1}$ mice to $\mathrm{F} 9$

\begin{tabular}{lcc}
\hline & Tumor-negative mice & Tumor-positive mice \\
\hline Irradiated hybrids & 1 & 20 \\
Nonirradiated hybrids & 19 & 5 \\
\hline
\end{tabular}

Mice were irradiated as described in Materials and Methods. Irradiated mice and their age- and sexmatched controls received a sublethal challenging of F9 cells $\left(2.5 \times 10^{4}\right)$ subcutaneously bilaterally using the same cell suspension. 
Table 7. Resistance of $129 \longleftarrow \mathrm{F}_{1}$ chimeras to $\mathrm{F} 9$

\begin{tabular}{lcc}
\hline & Tumor-negative mice & Tumor-positive mice \\
\hline 129 & 4 & 25 \\
F $_{1}$ & 22 & 9 \\
Chimeras & 16 & 12 \\
\hline
\end{tabular}

Construction of $129 \leftarrow \mathrm{F}_{1}$ chimeras is described in Materials and Methods. Chimeras, 129 controls, and $\mathrm{F}_{1}$ controls were age-matched and were challenged at the same time from the same cell suspension. All animals received $2.5 \times 10^{4} \mathrm{~F} 9$ cells subcutaneously bilaterally, a dose that is lethal for the 129 strain but sublethal for the $F_{1}$ strain.

resistance is eliminated by sublethal doses of total-body irradiation, (b) hybrid resistance is adoptively transferred via lymphoid cells from a naive $F_{1}$ mouse, and (c) the resistance of the hybrids is heightened by preimmunization using live tumor cells. The positive effect of preimmunization, although not large, gives important evidence that hybrid resistance is immunological.

Does preimmunization heighten the same immune-response channel as that operating in hybrid resistance? Or, does it act in animals protected by hybrid resistance to heighten other channels? We have not tested whether syngeneic hosts can be preimmunized by live tumor cells; the doses sublethal for $\mathrm{F}_{1}$ hosts would be lethal in syngeneic hosts. We note with interest the report of Boon and Van Pel (1978) that syngeneic hosts can be preimmunized by live attenuated $\left(\mathrm{tum}^{-}\right)$ embryonal carcinoma variants. It is possible that $F_{1}$ resistance operates on the same channel as that elicited in the syngeneic host by Boon and Van Pel's procedure.

Our experiments do not permit identification of the embryonal carcinoma antigen(s) to which the $\mathrm{F}_{1}$ hybrid responds. It is unlikely to be encoded at the $H-2$ locus because the $(6 \mathrm{M} \times 129) \mathrm{F}_{1}$ is fully syngeneic at this locus but shows unabated hybrid resistance.

Hybrid resistance is also unlikely to be directed against the male-specific antigen H(Y). PCC3 lacks the Y chromosome (Nicolas et al. 1976), and we have observed no difference in the level of resistance between male and female hybrids (data not shown).

A third unlikely candidate for the transplantation antigen against which hybrid resistance is directed is the F9 antigen (Artzt et al. 1974, Kemler et al. 1976, Marticorena et al. 1978). This embryonic antigen is immunogenic in the syngeneic host, as judged by serological response; for it to form the basis of graft rejection in hybrids and not in the syngeneic host would thus require an additional hypothesis.

One interesting candidate for the transplantation antigen for hybrid resistance is the antigen associated with the Gross leukemia virus, $\mathrm{G}_{I X}$. This antigen is found on adult lymphoid cells and in some malignant tissues; 129 is a positive strain, whereas B6 is negative (Klein 1975). Obata and his co-workers (1976) have studied the genetic control of the serological response to $\mathrm{G}_{\mathrm{IX}}$. Although the syngeneic strain 129 is antigen-positive and seronegative, and the antigen-positive congenic strain B6.129 is also seronegative, the $F_{1}$ hybrids $(129 \times B 6)$ and $(129 \times B 6.129)$ are seropositive. These workers have suggested that B6 and 129 carry dominant immune-response factors that cooperate to permit a serological response to the $\mathrm{G}_{I X}$ auto-antigen encoded by the 129 genome. 
Though embryonal carcinoma cells in culture show no evidence for virus growth (Jacob 1977), it is not known whether F9 or PCC3 carry the $\mathrm{G}_{I x}$ antigen. Its involvement in hybrid resistance is, therefore, only conjectural at this time.

The studies reported here demonstrate that resistance of $(129 \times \mathrm{B} 6)$ hybrids to F9 teratocarcinoma transplants is mediated by lymphoid tissue and does not depend upon heterozygosity at the $H-2$ locus. The multipotent line PCC3 is also susceptible to hybrid resistance. Semisyngeneic hybrids involving $\mathrm{A} / \mathrm{J}$ or $\mathrm{SJL} / \mathrm{J}$ as the allogeneic parent also display hybrid resistance to F9 and PCC3. The target antigen(s) and the immune mechanisms(s) of transplant rejection remain to be determined.

Acknowledgements. This work was supported by Program-Project Grant 1-PO1-CA-23076 in tumor biology to the McArdle Laboratory from the National Cancer Institute. G.A.B. has been supported by Training Grant 5T32-CA09135 to the McArdle Laboratory; this work has been submitted to the University of Wisconsin in partial fulfillment of the requirements for an M.S. degree in Oncology. We thank Professor Carter Denniston for help with statistical evaluation and Professor Kelly Clifton for the use of his cesium irradiator. Finally, our colleagues Linda Clipson, Alexandra Shedlovsky, and Bette Sheehan have helped with criticism of the manuscript.

\section{References}

Artzt, K., Bennett, D., and Jacob, F.: Primitive teratocarcinoma cells express a differentiation antigen specified by a gene at the T-locus in the mouse. Proc. Natl. Acad. Sci. U.S.A. 71:811-814, 1974

Avner, P. R., Dove, W. F., DuBois, P., Gaillard, J. A., Gućnet, J.-L., Jacob, F., Jakob, H., and Shedlovsky, A.: The genetics of teratocarcinoma transplantation: tumor formation in allogeneic hosts by the embryonal carcinoma cell lines F9 and PCC3. Immunogenetics 7: 103-115, 1978

Boon, T. and Van Pel, A.: Teratocarcinoma cell variants rejected by syngeneic mice: protection of mice immunized with these variants against other variants and against the original malignant cell line. Proc. Natl. Acad. Sci. U.S.A. 75:1519-1523, 1978

Clark, E. A., Harmon, R. C., and Wicker, L. S.: Resistance of $H$-2 heterozygous mice to parental tumors. II. Characterization of $H h-1$ controlled hybrid resistance to syngeneic fibrosarcomas and the EL-4 lymphoma. J. Immunol. 119: 648-656, 1977

Conover, W. J.: Practical Nonparametric Statistics. John Wiley and Sons. Inc., New York, 1971

Cudkowicz, G.: Hybrid resistance to parental grafts of hematopoietic and lymphoma cells. In The Proliferation and Spread of Neoplastic Cells, XXI Anmul M. D. Anderson Symposium on Fundamental Cancer Research, pp. 661-691, Williams and Wilkins Co., Baltimore, 1967

Hauschka, T. S., Kvedar, B. J., Grinnell, S. J., and Amos, D. B.: Immunoselection of polyploids from predominantly diploid cell populations. Ann. N. Y. Acad. Sci. 63: 683-705, 1956

Jacob, F.: Mouse teratocarcinoma and embryonic antigens. Immunol. Rev. 33: 3-32, 1977

Kemler, R., Babinet, C., Condamine, H., Gachelin, G., Gıénet, J.-L., and Jacob, F.: Embryonal carcinoma antigen and the $T / t$ locus of the mouse. Proc. Natl. Acad. Sci. U.S.A. $73: 4080-4084,1976$

Kiessling, R., Petranyi, G., Klein, G., and Wigzell, H.: Genetic variation of in vitro cytolytic activity and in vivo rejection potential of non-immunized semi-syngeneic mice against a mouse lymphoma line. Int. J. Cancer 15: 933-940, 1975

Klein, G., Klein, G. O., Kärre, K., and Kiessling, R.: "Hybrid resistance” against parental tumors: one or several genetic patterns? Immunogenetics 7: 391-404, 1978

Klein, J.: Biology of the Mouse Histocompatibility-2 Complex. Springer-Verlag, New York, 1975

Luna, L. (ed.): Manual of Histologic Staining Methods of the Armed Forces Institute of Pathology, p. 17, Method I, McGraw Hill Co., New York, 1968

Marticorena, P., Artzt, K., and Bennett, D.: Relationship of F9 antigen and genes of the $T / t$ complex. Intmunogenetics 7: 337-347, 1978

Nicolas, J. F., Avner, P., Gaillard, J., Guénet, J.-L., Jakob, H., and Jacob, F.: Cell lines derived from teratocarcinomas. Cancer Res. 36: 4224-4231, 1976 
Obata, Y., Stockert, E., Boyse, E. H., Tung, J., and Litman, G. W.: Spontaneous autoimmunization to $\mathrm{G}_{1 \times}$ cell surface antigen in hybrid mice. J. Exp.Med. 144:533-542, 1976

Sanford, B. H. and Soo, S. F.: Resistance to transplants of recent spontaneous parental line tumors by $F_{1}$ hybrid hosts. J. Natl. Cancer Inst. 46:95-101, 1971

Schmitt-Verhulst, A. and Zatz, M. M.: F, resistance to AKR lymphoma cells in vitro and in vivo. J. Immunol. 118: 330-333, 1977

Snell, G. D.: The genetics of transplantation. J. Nall. Cancer Inst. 14: 691-700, 1953

Snell, G. D.: Histocompatibility genes of the mouse. I. Demonstration of weak histocompatibility differences by immunization and controlled tumor dosage. J. Natl. Cancer Inst. 21: 843-877, 1958

Stevens, L. C.: The development of transplantable teratocarcinomas from intratesticular grafts of preand postimplantation mouse embryos. Dev. Biol. 21: 364-382, 1970

Received December 10, 1979 